\title{
To What Extent Do Food Preferences Explain the Trophic Position of Heterotrophic and Mixotrophic Microbial Consumers in a Sphagnum Peatland?
}

\author{
Vincent E. J. Jassey • Caroline Meyer • Christine Dupuy • \\ Nadine Bernard • Edward A. D. Mitchell • Marie-Laure Toussaint • \\ Marc Metian • Auriel P. Chatelain • Daniel Gilbert
}

Received: 9 April 2013 / Accepted: 21 June 2013 /Published online: 10 July 2013

(C) Springer Science+Business Media New York 2013

\begin{abstract}
Although microorganisms are the primary drivers of biogeochemical cycles, the structure and functioning of microbial food webs are poorly studied. This is the case in Sphagnum peatlands, where microbial communities play a key role in the global carbon cycle. Here, we explored the structure of the microbial food web from a Sphagnum peatland by analyzing (1) the density and biomass of different microbial functional groups, (2) the natural stable isotope $\left(\delta^{13} \mathrm{C}\right.$ and $\left.\delta^{15} \mathrm{~N}\right)$ signatures of key microbial consumers (testate amoebae), and (3) the digestive vacuole contents of Hyalosphenia papilio, the dominant testate amoeba species in our system. Our results showed
\end{abstract}

Vincent E. J. Jassey and Caroline Meyer contributed equally to this work.

V. E. J. Jassey $\cdot$ C. Meyer · N. Bernard · M.-L. Toussaint •

D. Gilbert

UMR CNRS/UFC 6249, Laboratoire Chrono-Environnement,

Université de Franche-Comté, 25211 Montbéliard Cedex, France

V. E. J. Jassey

Ecological Systems Laboratory (ECOS), School of Architecture,

Civil and Environmental Engineering (ENAC),

Ecole Polytechnique Fédérale de Lausanne (EPFL),

Station 2, 1015 Lausanne, Switzerland

V. E. J. Jassey $(\bowtie)$

Swiss Federal Institute for Forest, Snow and Landscape Research (WSL), Site Lausanne, Station 2, 1015 Lausanne, Switzerland e-mail: vincent.jassey@epfl.ch

\section{Dupuy $\cdot$ M. Metian}

UMR CNRS 7266, Laboratoire Littoral Environnement et Sociétés, Université de La Rochelle, 17000 La Rochelle, France

E. A. D. Mitchell • A. P. Chatelain

Laboratory of Soil Biology, University of Neuchâtel,

Rue Emile-Argand 11, CH-2000 Neuchâtel, Switzerland that the feeding type of testate amoeba species (bacterivory, algivory, or both) translates into their trophic position as assessed by isotopic signatures. Our study further demonstrates, for $H$. papilio, the energetic benefits of mixotrophy when the density of its preferential prey is low. Overall, our results show that testate amoebae occupy different trophic levels within the microbial food web, depending on their feeding behavior, the density of their food resources, and their metabolism (i.e., mixotrophy vs. heterotrophy). Combined analyses of predation, community structure, and stable isotopes now allow the structure of microbial food webs to be more completely described, which should lead to improved models of microbial community function.

\section{Introduction}

The way in which community structure and species attributes determine fluxes of energy in ecosystems is an important topic in ecology. The study of food webs provides a quantitative framework in our understanding of links between community structure and ecosystem functioning [1]. Food webs are networks determining the number and direction of trophic interactions in ecosystems and provide a natural framework for understanding the ecological role of species. Identifying how and to what extent these webs are structured is necessary if we hope to move beyond a "black box" approach and toward a more mechanistic understanding of the ecosystem processes and functions that they drive [2-6]. However, the presence of incompletely described feeding relationships hampers our understanding of complex and dynamic food webs in nature [7]. A clear example is the scarcity of existing data on microbial food webs, which, for 
practical reasons, are often limited to experimental studies using a very limited number of taxa and often in combinations that do not reflect any natural system [8-11].

A major impediment in determining microbial food web structure probably stems from the difficulty in identifying interspecific links and collecting the required quantitative dietary data. Microbial communities are composed of numerous (and often poorly described or altogether unknown) species that can form complex food webs with numerous feeding links. Discovering the structure of these food webs is important because they may affect processes occurring at the population, community, and ecosystem levels [7]. The true trophic position (TP) and diversity in trophic roles of different microbial species and/or species group of different species were, until recently, all but impossible to determine. The increasing sensitivity of analytical tools now makes it possible to study ever-smaller organisms using stable isotope probing $[8,12]$. Stable isotope ratios of carbon and nitrogen are increasingly used to provide time-integrated information about feeding relationships and food web structure, as showed for aquatic food webs [13-15]. By providing a temporally and spatially averaged estimate of carbon and nitrogen that is actually assimilated by organisms [16], stable isotopes can improve our estimates of the major pathways of energy flows through microbial food webs [17].

We focused here on microbial communities living in Sphagnum peatlands. In this diverse community, a group of protozoa, the testate amoebae, is especially abundant. Testate amoebae represent an ideal model group for microbial food web studies in terrestrial ecosystems owing to their abundance, diversity, and ubiquity [18]. Testate amoebae are usually considered as feeding on a wide range of food sources, such as bacteria, fungi, microalgae, ciliates, rotifers, and nematodes [12, 19-22]. As a result, they are considered top predators in microbial food webs [23-25]. As such, they play an important role in carbon and nutrient cycling in soils [26-29]. However, in order to understand the role of testate amoebae in carbon and nutrient cycling, key aspects of their ecology need to be understood, including how they obtain energy and nutrients. Precise information on the feeding habits of testate amoebae is limited to a few species [29]. The broad range of sizes (approximately $5-500 \mu \mathrm{m}$ in length, corresponding to volumes spanning six orders of magnitude) and high diversity of morphologies and functional traits found among testate amoebae $[18,30]$ suggest that they play different functional roles in microbial food webs. Species commonly described as omnivores probably occupy a different trophic level in the microbial network than specific feeders such as bacterivores or predators. Furthermore, many pigmented (photosynthetic) microorganisms are known or suspected to be mixotrophic (i.e., organisms that combine autotrophy and heterotrophy using endosymbiotic zoochlorellae); these include several testate amoeba species such as Hyalosphenia papilio and Archerella flavum [31,32], species that are commonly found in northern Sphagnum peatlands (e.g., [18, 33-36]). The mixotrophic life trait has significant functional and physiological implications [10, 37, 38] and should theoretically translate into distinct isotopic ratios. Hence, the use of isotopic analyses may provide a mechanistic understanding on how testate amoebae are trophically structured, highlighting the strategy and functional role of dominant species in the food web.

Here, we aim to track energy flow through microbial food chains from lower to higher trophic levels to disentangle the trophic structure of testate amoeba populations in the microbial food web and to elucidate the role of the mixotrophic strategy in microbial food web functioning. We hypothesize that the trophic level-based on isotopic enrichment - of testate amoebae within the microbial network relates to their feeding habit (bacterivory, algivory, and predation) and metabolism (heterotrophy vs. mixotrophy). Considering the key role of foraging traits such as density of prey in the feeding habit of testate amoebae [12], we also hypothesize that prey density affects the TP of testate amoebae. For this, we explored the microbial food web associated with Sphagnum moss by combining predation of testate amoebae (digestive vacuole contents and predator-prey associations), analyses of community density and biomass, and isotopic signatures $\left(\delta^{13} \mathrm{C}\right.$ and $\left.\delta^{15} \mathrm{~N}\right)$ of testate amoebae and their potential prey, including microalgae, cyanobacteria, rotifers, and nematodes.

\section{Materials and Methods}

\section{Study Area and Experimental Design}

We sampled one peat monolith $(43.5 \times 33.5 \mathrm{~cm}, 22 \mathrm{~cm}$ in depth) in a macroscopically homogeneous Sphagnum fallax lawn in a peatland in the Jura Mountains (Sur-les-Seignes, Frambouhans-Les Ecorces, France; $47^{\circ} 18^{\prime} \mathrm{N}, 6^{\circ} 79^{\prime} \mathrm{E}$ ) in late November 2010. The core was then placed under controlled conditions to quickly reactivate microbial life: an average temperature of $22^{\circ} \mathrm{C}$ (day) and $18^{\circ} \mathrm{C}$ (night), a light cycle of $16 / 8 \mathrm{~h}$ (light/dark), and a light intensity of $0.029 \mathrm{~kW} \mathrm{~m}^{-2}$. The depth to water table was maintained at constant level ( $6.5 \mathrm{~cm}$ below the top of the moss carpet) by adding standardized solution (Volvic water $=0.8 \mathrm{~L}$ every 2 days). We measured the physicochemical conditions of the peat core when the container was placed under controlled conditions. The temperature of the water table and at the surface was 5 and $12{ }^{\circ} \mathrm{C}$, respectively; $\mathrm{pH} 4.4$; and conductivity = $20.1 \mu \mathrm{S} \mathrm{cm} \mathrm{cm}^{-1}$. After 15 days, these values increased (average temperature of the water table and at the surface was 17 and $20^{\circ} \mathrm{C}$, respectively; $\mathrm{pH} 4.9$; and conductivity = $44.1 \mu \mathrm{S} \mathrm{cm}^{-1}$ ) and stabilized. 
After 15 days, the Sphagnum carpet from the peat monolith was subdivided into three subsamples. For each subsample, the totality of the living apical green segments of Sphagnum shoots (top $3 \mathrm{~cm}$ ) was collected. We randomly sampled $5 \mathrm{~g}$ of fresh material (approximately 15 shoots) in each subplot and fixed it in $20 \mathrm{~mL}$ of glutaraldehyde ( $2 \%$ final concentration) for microbial community analysis (density, biomass, and diversity). The remaining material was used for isotopic analyses. Fully opened healthy capitula of Sphagnum (top $3 \mathrm{~cm}$ ) were also sampled and lyophilized for isotopic analyses. No moss was taken from the marginal $5-\mathrm{cm}$ border zone of the peat monolith to avoid possible border effects.

\section{Microscopic and Isotopic Analyses}

All microorganisms were extracted from $S$. fallax following the method used by Jassey et al. [12]. Microalgae, cyanobacteria, protozoa, rotifers, nematodes, and fungi were identified and quantified at $\times 400$ magnification by means of inverted microscopy (Olympus IX71) and following Uthermöhl's method [39]. Bacterial density was estimated by flow cytometry (FACSCalibur flow cytometer, Becton Dickinson). Fluorescent microbeads (molecular probes) $1 \mu \mathrm{m}$ in diameter were added to each sample as an internal standard. Bacteria were stained with SYBR Green I (1/10,000 final concentration) for $15 \mathrm{~min}$ in the dark and samples run at medium speed $\left(40 \mu \mathrm{min}^{-1}\right)$. Bacterial size was estimated by epifluorescence microscopy using image analysis. The feeding habit of the dominant testate amoeba species, H. papilio, was studied in detail. To this aim, a total of 670,715 , and 500 specimens of $H$. papilio were observed by inverted microscopy in the three subsamples, respectively. Among active specimens, we distinguished between individuals with a prey within the shell and those that were actively feeding (determined as attached to prey or organic matter particles) to determine the feeding habit of this species, as described in Gilbert et al. [20]. Such an analysis was not possible for other testate amoeba species due to their low abundance.

The biovolume of each morphospecies or group was estimated using geometrical shapes and then converted to carbon using the following conversion factors: heterotrophic bacteria, $1 \mu \mathrm{m}^{3}=5.6 \times 10^{-7} \mu \mathrm{gC}$ [40]; cyanobacteria and microalgae, $1 \mathrm{~m}^{3}=1.2 \times 10^{-7} \mu \mathrm{gC}$; ciliates and testate amoebae, 1$\mu \mathrm{m}^{3}=1.1 \times 10^{-7} \mu \mathrm{gC}$ [41]; fungi $1 \mu^{3}=2.5 \times 10^{-7} \mu \mathrm{gC}$; and nematodes and rotifers, $1 \mu \mathrm{m}^{3}=1.25 \times 10^{-7} \mu \mathrm{gC}$ [42]. These data were expressed as microgram $C$ per gram of $S$. fallax dry mass (DM).

Collection and preparation of microbial samples for isotopic analyses follow Jassey et al. [12]. We measured the isotopic signatures of cyanobacteria + microalgae $(\mathrm{CA})$, fine organic matter including bacteria (FOMB), two abundant groups of micrometazoa, small nematodes $(<200 \mu \mathrm{m})$ and rotifers, and the dominant testate amoeba species Arcella vulgaris, A. flavum, Bullinularia indica, Euglypha compressa, H. papilio, and Nebela tincta. Microorganisms were extracted from fresh moss by six successive rinsing of $S$. fallax using distilled water and successively filtered at 150, 120, 70, 50, 30,20 , and $11 \mu \mathrm{m}\left(\right.$ SEFAR NITEX $\left.{ }^{\circledR}\right)$. The fraction under $11 \mu \mathrm{m}$ was used for FOMB and CA. For FOMB, the fraction was centrifuged at $15,000 \mathrm{rpm}$ for $20 \mathrm{~min}$. Then, the supernatant was centrifuged again at $10,000 \mathrm{rpm}$ for $10 \mathrm{~min}$ and the pellet was used for isotopic measurements. All other categories were handpicked randomly and individually using micropipettes. Between 50 and 1,500 living testate amoeba specimens of the selected species were collected in each subsample, depending on their size (Table 1). In order to obtain reliable measurements, $0.1 \mathrm{mg}$ of matter is required for isotopic measurement. To reach this amount, some samples had to be pooled from the three subplots, A. vulgaris, A. flavum, B. indica, E. compressa, $N$. tincta, rotifers, and nematodes, and for these, no replicated measurements could be obtained. After 3 days, we also collected the CA biofilm using a micropipette. We estimated trophic positions (TP) following the method of Post [43]. We used S. fallax capitula as the baseline of the network for estimating TPs using $\delta^{15} \mathrm{~N}$ because we focused on microbial communities living in Sphagnum moss, and Sphagnum integrates temporal and spatial variations in isotopic signatures of basal resources [43].

\section{Data Analysis}

We used linear mixed effects models to test for relationships between (1) $\delta^{13} \mathrm{C}$ and $\delta^{15} \mathrm{~N}$ signatures of microbial species/groups and between (2) $\delta^{15} \mathrm{~N}$ and testate amoeba morphological traits (i.e., body size - length or diameter-shell aperture size and biovolume). These models were built while accounting for the pseudoreplication measurements in the peat monolith. We fitted all models including subplot as a random effect on the intercept, i.e., we corrected for the inflation of the residual degrees of freedom that would occur if we were using repeated measurements as true replicates. Regression diagnostics (leverage and outliers effects) and global validations of linear model assumptions (normality of the data distribution and homogeneity of variance) were examined and tested as described by Fox and Weisberg [44].

Differences in TP of the identified groups or species were assessed using nonparametric Mann-Whitney tests. A hierarchical cluster analysis using the Ward distance method and Bray-Curtis dissimilarity index were computed on $\delta^{13} \mathrm{C}$ and $\delta^{15} \mathrm{~N}$, isotopic nitrogen over carbon ratio, and trophic level values in order to identify feeding types of species and/or microbial groups. The robustness and the significance of the cluster were tested using bootstrap resampling (i.e., 1,000 resampling from the data).

All statistical analyses were performed with R 2.15.1 using the ade4, car, and pvclust packages [44-46]. 
Table 1 Number of specimen sampled ( $n$ ); weight of species sampled (in milligrams, mean \pm standard error); isotopic ratios (in per mille, mean \pm standard error) of carbon and nitrogen in S. fallax, microbial groups, and testate amoeba species; trophic level; feeding type; and strategy of microbial groups and testate amoeba species

\begin{tabular}{|c|c|c|c|c|c|c|c|c|c|}
\hline Group & $\begin{array}{l}\text { Species } \\
\text { name }\end{array}$ & $n$ & $\begin{array}{l}\text { Sample } \\
\text { weight (mg) }\end{array}$ & $\begin{array}{l}\delta^{13} \mathrm{C} \\
(\%)\end{array}$ & $\begin{array}{l}\delta^{15} \mathrm{~N} \\
(\%)\end{array}$ & $\begin{array}{l}\text { Trophic } \\
\text { level }\end{array}$ & $\begin{array}{l}\text { Feeding } \\
\text { type }^{\mathrm{a}}\end{array}$ & $\begin{array}{l}\text { Feeding } \\
\text { strategy }\end{array}$ & \\
\hline Bryophyte & Sphagnum fallax & & $0.93 \pm 0.01$ & $-28.0 \pm 0.2$ & $-5.4 \pm 0.1$ & 1.0 & & Autotroph & \\
\hline $\begin{array}{l}\text { Particulate } \\
\text { matter+bacteria }\end{array}$ & & & $0.83 \pm 0.04$ & $-27.3 \pm 0$ & $-1.9 \pm 0.2$ & 2.0 & $1 \mathrm{~A}$ & & \\
\hline Microalgae $^{\mathrm{b}}$ & & & $0.96 \pm 0.1$ & $-26.8 \pm 0.1$ & $-6.7 \pm 1.4$ & 1.0 & $0 \mathrm{~A}$ & Autotroph & \\
\hline \multirow[t]{6}{*}{ Testate amoebae } & Arcella vulgaris ${ }^{\mathrm{b}}$ & 250 & 0.23 & -26.8 & -0.97 & 2.3 & $2 \mathrm{C}$ & $\mathrm{B}, \mathrm{CA}, \mathrm{Fu}$ & {$[21]$} \\
\hline & Archerella flavum $^{\mathrm{b}}$ & 4,500 & 0.46 & -25.7 & 1.0 & 2.9 & $2 \mathrm{~A}$ & B & $\begin{array}{l}\text { Lara, personal } \\
\text { communication }\end{array}$ \\
\hline & Bullinularia indica $^{\mathrm{b}}$ & 330 & 0.19 & -26.4 & -0.97 & 2.3 & $2 \mathrm{C}$ & $\mathrm{B}, \mathrm{CA}$ & Present paper \\
\hline & Euglypha compressab & 50 & 0.07 & -25.0 & -0.93 & 2.3 & $2 \mathrm{C}$ & $\mathrm{B}, \mathrm{CA}$ & [19] \\
\hline & Hyalosphenia papilio & 1,800 & $0.51 \pm 0.05$ & $-21.6 \pm 0.5$ & $-1.2 \pm 0.1$ & 2.3 & $2 \mathrm{~B}$ & $\begin{array}{c}\mathrm{CA}, \mathrm{Fu}, \mathrm{Fl}, \\
\mathrm{Ci}, \mathrm{T}, \mathrm{M}\end{array}$ & {$[12]$} \\
\hline & Nebela tincta $^{\mathrm{b}}$ & 150 & 0.07 & -25.9 & -0.6 & 2.4 & $2 \mathrm{C}$ & $\begin{array}{c}\mathrm{CA}, \mathrm{Fu}, \mathrm{Fl} \\
\quad \mathrm{Ci}, \mathrm{T}, \mathrm{M}\end{array}$ & {$[12,19,20]$} \\
\hline Rotifers $^{\mathrm{b}}$ & & 300 & 0.09 & -24.3 & -0.5 & 2.4 & $2 \mathrm{C}$ & $\begin{array}{l}\text { Filter } \\
\text { feeders }\end{array}$ & \\
\hline Nematodes $^{\mathrm{b}}$ & & 300 & 0.16 & -25.4 & 0.5 & 2.7 & $2 \mathrm{~A}$ & B & [64] \\
\hline
\end{tabular}

Food sources: $B$ bacteria, $F u$ fungi, $C A$ cyanobacteria and microalgae, $F l$ flagellates, $C i$ ciliates, $T$ testate amoebae, $M$ micrometazoan (rotifers, nematodes). Feeding type: $O A$ photosynthetic organism (protist), $1 A$ OM feeders, $2 A$ bacterivores, $2 B$ primary producer feeders, $2 C$ bacteria and primary producer feeders

${ }^{\text {a }}$ Adaptive from [8]

${ }^{\mathrm{b}}$ Pooled species

\section{Results}

\section{Microbial Community Structure}

In terms of biomass, the microbial community was composed of $53 \%$ decomposers (bacteria and fungi), $17.3 \%$ microbial primary producers (microalgae and cyanobacteria), and $29.8 \%$ consumers (all other groups; Fig. 1a). Bacteria accounted for almost half of the total biomass $\left(726 \pm 232 \mu \mathrm{gC} \mathrm{g} \mathrm{g}^{-1}\right.$ $\mathrm{DM})$, while fungi represented only $6.6 \%(103 \pm 53 \mu \mathrm{gC}$ $\mathrm{g}^{-1}$ DM; Fig. 1). Testate amoebae represented about one quarter of the total biomass $\left(413 \pm 176 \mu \mathrm{gC} \mathrm{g} \mathrm{g}^{-1} \mathrm{DM}\right)$ and were the dominant group of consumers, while rotifers made up only $3.1 \%$ of the total biomass $\left(49 \pm 37 \mu \mathrm{gC} \mathrm{g}^{-1} \mathrm{DM}\right.$; Fig. 1a). Ciliates and nematodes together represented less than $1 \%$ of the total biomass ( $3 \pm 1$ and $2 \pm 0 \mu \mathrm{gC} \mathrm{g}^{-1} \mathrm{DM}$, respectively). Primary producers were dominated by microalgae (14.7 \% of the total biomass), while cyanobacteria accounted for a much lower fraction of the total biomass (approximately $2.6 \%$ ). The green alga Cylindrocystis brebissonii was the more abundant species of microalgae with more than $90 \%$ of the microalgal biomass, whereas Aphanothece nidulans and Anabaena cylindrica were the most abundant species of cyanobacteria (54 and $34 \%$ of cyanobacteria biomass, respectively). $H$. papilio strongly dominated the testate amoeba community and accounted for $89.8 \%$ of its biomass (Fig. 1b).
Feeding Habit of $H$. papilio: Digestive Vacuole Contents Approach

On average, $25 \%$ of the observed $H$. papilio specimens were associated with prey. Among the identified food sources, $80 \%$ were microbial primary producers $(\mathrm{CA}=$ microalgae and cyanobacteria, e.g., A. nidulans), $12 \%$ were fungi (including hyphae of ascomycetes and spores of Helicoon pluriseptatum), and $6 \%$ were ciliates (e.g., Platyophrya sphagni) (Table 2). Predation on other testate amoebae (e.g., A. flavum), rotifers (e.g., Habrotrocha sp. and Colurella sp.), and nematodes was observed only rarely $(<1 \%$ of the total identified predator-prey associations). These proportions matched very closely the density of these organisms in the environment (Table 2). These frequencies represented, in terms of grazed biomass, $9.8 \%$ of the biomass of CA, $20.1 \%$ of that of fungi, and $49.3 \%$ of that of ciliates.

\section{Isotopic Composition of the Microbial Food Web}

The isotopic values of cyanobacteria and microalgae (CA) $\left(\delta^{13} \mathrm{C}=-26.8 \% ; \delta^{15} \mathrm{~N}=-6.7 \%\right.$ ) were almost identical to that of Sphagnum $\left(\delta^{13} \mathrm{C}=-28.0 \%\right.$; $\delta^{15} \mathrm{~N}=-5.4 \%$, which is therefore used as a baseline for further interpretation. By contrast, all other microbial groups yielded enriched $\delta^{13} \mathrm{C}$ and $\delta^{15} \mathrm{~N}$ values relative to the baseline value determined from $S$. fallax shoots (Fig. 2; Table 1). 


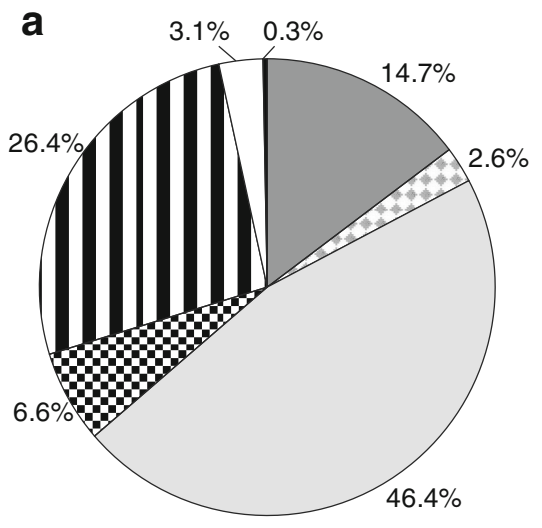

b

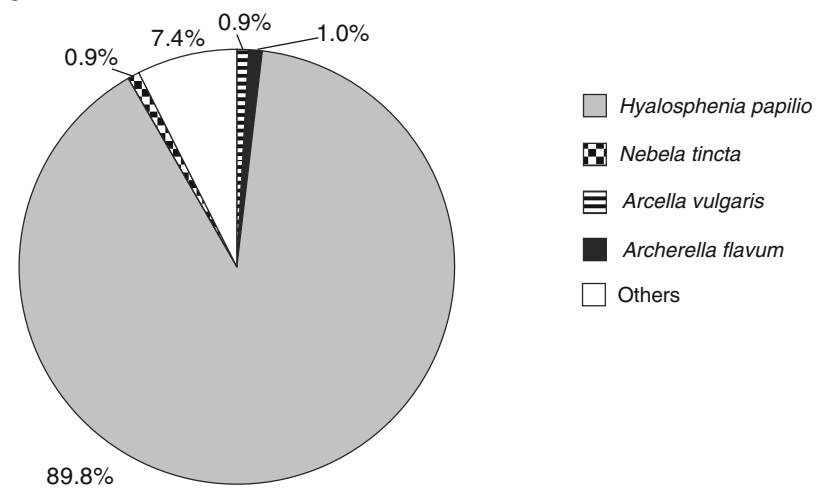

Fig. 1 a Relative biomass of different microbial groups (percent of the total microbial community) in a S. fallax carpet. b Relative abundance (in percent) of the main testate amoeba species (percent of the total testate amoeba community)

The $\delta^{13} \mathrm{C}$ and $\delta^{15} \mathrm{~N}$ signatures of consumers covered a broad range of values, from -27.3 to $-21.6 \%$ and from -1.9 to $+1 \%$, respectively. Isotopic values were significantly higher in consumers (testate amoebae, rotifers, and nematodes) as compared to primary producers (S. fallax and CA; $P=0.04, r=0.5$ ). For instance, the isotopic diagram showed that $A$. flavum was more enriched in $\delta^{13} \mathrm{C}(+1.6 \%)$ and $\delta^{15} \mathrm{~N}(+2.9 \%)$ than FOMB (Fig. 2). Isotopic values of $A$. vulgaris $\left(\delta^{13} \mathrm{C}=+0.3 \% ; \delta^{15} \mathrm{~N}=\right.$ $+2.1 \%)$, B. indica $\left(\delta^{13} \mathrm{C}=+0.7 \%\right.$; $\delta^{15} \mathrm{~N}=+3 \%$ ), and $N$. tincta $\left(\delta^{13} \mathrm{C}=+0.3 \% ; \delta^{15} \mathrm{~N}=+1.7 \%\right.$ ) were also consistently enriched relative to those of their supposed diet (CA) (Fig. 2; Table 1).
Our results also showed that the mixotrophic species $H$. papilio was highly enriched in $\delta^{13} \mathrm{C}(+5.2 \%)$, as compared to its diet (CA) (Fig. 2; Table 2). This was not the case for the other mixotrophic species studied (A. flavum).

Translating these results into TP, primary producers (CA) had the same trophic level as $S$. fallax in the microbial food web $(\mathrm{TP}=1)$, while FOMB $(\mathrm{TP}=2)$ and consumers (TP ranged from 2.3 to 2.9 ) had significant higher trophic level than primary producers $(P<0.05)$ (Table 1 ; Fig. $3 b)$. In the cluster analysis, microbial groups were split into primary producers and consumers. The microbial consumers were further split into five subgroups corresponding to different feeding strategies (Fig. 3a, b; Table 1). The first subgroup corresponded to mixotrophic algivores (C1) composed of $H$. papilio (Fig. 3). The second subgroup included decomposers (FOMB; C2), while the third and fourth subgroups corresponded to bacterivores (C3), including A. flavum and nematodes, and heterotrophic algivores (C4), including $A$. vulgaris, B. indica, and N. tincta (Fig. 3; Table 1). The fifth subgroup (C5) included E. compressa and rotifers and corresponded to a mix between algivores and bacterivores (Fig. 3; Table 1). Furthermore, we found that the trophic level of $H$. papilio was linked to the contribution of ciliates and CA to its total diet (Fig. 4). We found that the trophic level of $H$. papilio increased with the rise of ciliates and the decrease of CA in its total diet (Fig. 4a, b).

The $\delta^{15} \mathrm{~N}$ values of testate amoebae were negatively correlated to simple morphological traits such as the size of their shell aperture $(r=-0.86, P=0.02)$ and their biovolume $(r=-0.88, P=0.01)$, while no significant correlation was found with their body size (length or diameter) $(r=-0.72$, $P=0.07$, ANOVA).

\section{Discussion}

We investigated the trophic structure of the microbial food web associated to Sphagnum moss by combining the analyses of microbial density and biomass, stable isotopes $\left(\delta^{13} \mathrm{C}\right.$ and $\delta^{15} \mathrm{~N}$ ) of microbial groups, and digestive vacuole content of
Table 2 Relative proportion of the identified prey ingested by $H$. papilio. Relative proportion of the abundance of microbial groups in S. fallax, excluding bacteria. Relative proportion of the biomass of the identified prey ingested by $H$. papilio. $C A$ microalgae and cyanobacteria

\begin{tabular}{lllc}
\hline & $\begin{array}{l}\text { Frequency of the preys ingested } \\
\text { by H. papilio (\%) }\end{array}$ & $\begin{array}{l}\text { Frequency of identified } \\
\text { prey (\%) }\end{array}$ & $\begin{array}{l}\text { Frequency of ingested } \\
\text { organisms in terms of } \\
\text { biomass (\%) }\end{array}$ \\
\hline CA & 80 & 82.4 & 9.8 \\
Fungi & 12 & 11.8 & 20.1 \\
Ciliates & 6 & 0.4 & 49.3 \\
Testate amoebae & 0 & 4.7 & $<0.1$ \\
Rotifers & 0.6 & 0.5 & 0.8 \\
Nematodes & 0 & 0.2 & $<0.1$ \\
\hline
\end{tabular}




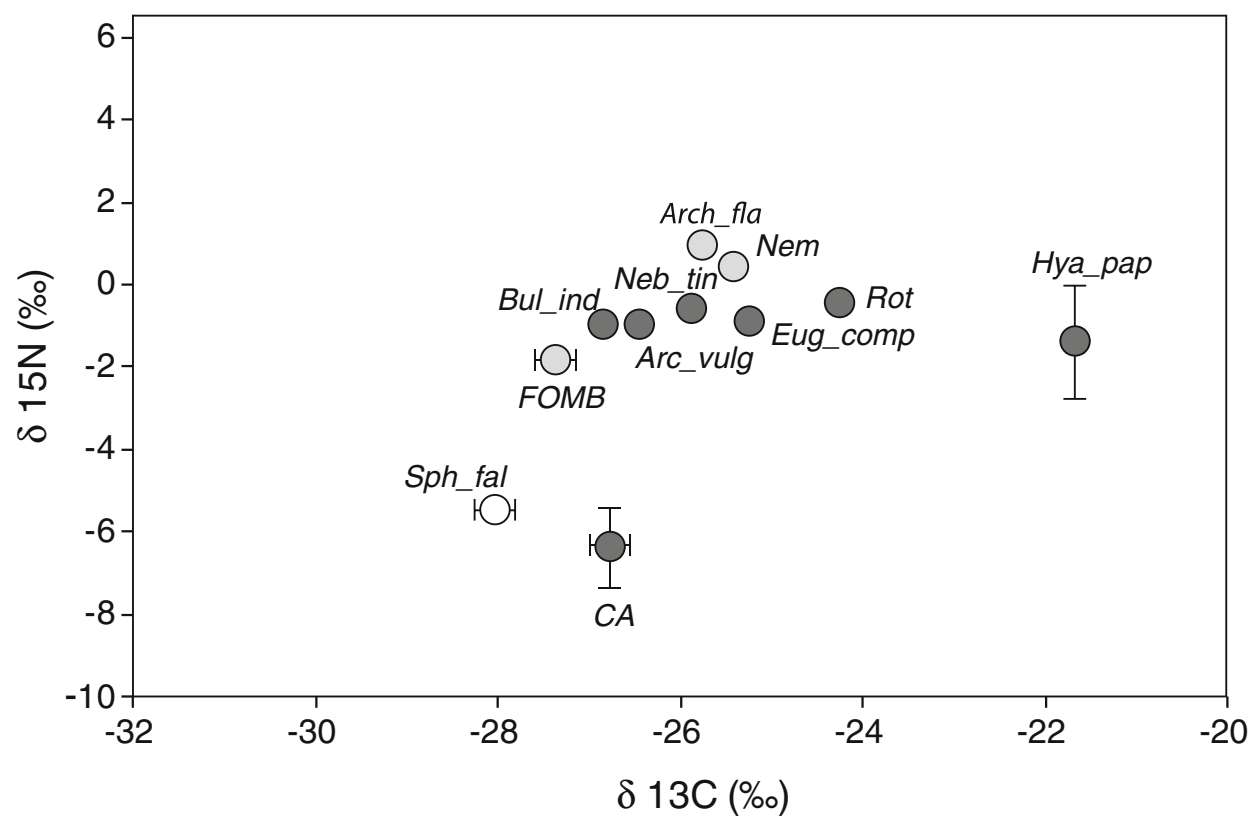

Fig. 2 Stable isotope $\left(\delta^{13} \mathrm{C}\right.$ and $\left.\delta^{15} \mathrm{~N}\right)$ food web diagram of the major microbial groups and testate amoeba taxa in $S$. fallax. Symbols are as follows: Sph_fal, S. fallax; CA, cyanobacteria + microalgae; Rot, rotifers; Nem, nematodes; FOMB, fine organic matter in association with bacteria; Arc_vulg, A. vulgaris; Arch_fla, A. flavum; Bul_ind, B. indica; Eug_comp, E. compressa; Hya_pap, H. papilio; and Neb_tin, N. tincta. Dark gray circles

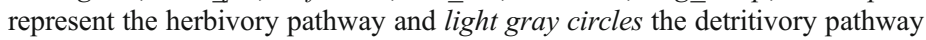

key microbial consumers. We found that the trophic level of microbial organisms inferred from stable isotopes was in line with expectations; bacteria (FOMB) have a higher trophic level than autotrophs (S. fallax, CA), and microbial consumers have a higher trophic level than both decomposers and autotrophs. We further showed that isotopic signatures of moss and CA did not differ and that both autotrophic microorganisms and Sphagnum mosses have similar directional shifting in food web space. This agrees with our assumption that autotrophs can be used as the baseline of the microbial food web associated to Sphagnum moss.

\section{Trophic Structure of the Microbial Food Web}

In most cases, we found isotopic enrichments in line with those of aquatic and soil food web in which consumer $\delta^{15} \mathrm{~N}$ signatures were higher than $3 \%$ [43, 47]. Based on these isotopic enrichments and identified feeding habit, we showed two trophic pathways in our microbial network: an herbivorous pathway and a detritivorous pathway. Firstly, we found a significant enrichment in $\delta^{15} \mathrm{~N}$ between microbial autotrophs (CA) and microbial consumers such as $N$. tincta, E. compressa, H. papilio, A. vulgaris, and rotifers, characterizing the herbivorous pathway. These isotopic enrichments indicated that these consumers mainly fed on CA in the current study. This agrees with our feeding observations on $H$. papilio, as well as with previous observations of feeding habits for A. vulgaris, E. compressa, and rotifers $[19,21,48,49]$. Secondly, the significant $\delta^{15} \mathrm{~N}$ enrichment between FOMB and consumers such as A. flavum and nematodes suggests the existence of a detritivorous pathway. $A$. flavum has been described as exclusively autotrophic [32], but its isotopic signature rather indicated that this species mainly fed on bacteria or fine organic particles (FOMB). Although food particles are rarely observed in A. flavum vacuoles, this does not exclude the possibility that bacteria occur in their vacuole. Indeed, bacteria are difficult to identify in testate amoeba vacuoles when using direct observation with epifluorescence microcopy (personal observation). Obviously, the recorded isotopic signatures do not exclude that microbial consumers feed on additional food sources and/or intermediate trophic level [50,51], as clearly showed for H. papilio.

More surprising is the difference between the isotopic signatures of $H$. papilio and $N$. tincta between this study and the one of Jassey et al. [12]. These results reflect intersite differences, showing that the isotopic signatures of a given species can be quite variable in space and/or time depending on environmental conditions [50]. However, the similar signature of the baseline (i.e., S. fallax) between the two studies also underlines differences of intersite food web functioning. The linkages between the TP of $H$. papilio and the contribution of the main categories of prey to its total diet agree with the hypothesis that differences in prey availability influence the TP of testate amoebae. Indeed, isotopic signatures and trophic levels of top predators, H. papilio and N. tincta $\left(\mathrm{TP}_{H}\right.$. papilio, 2.3 and $\mathrm{TP}_{N . \text { tincta }}, 2.4$ ), were significantly lower than those recently obtained by Jassey et al. [12] $\left(\mathrm{TP}_{H}\right.$. papilio 3.5 
a

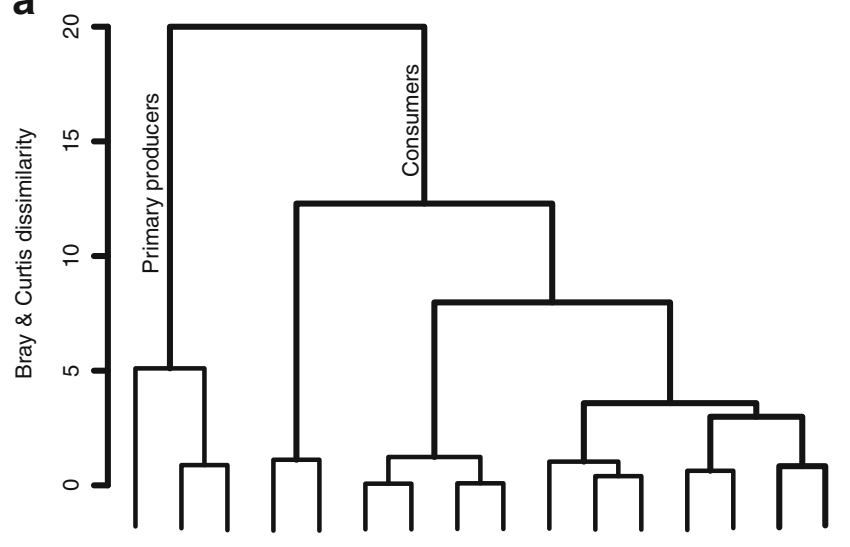

b

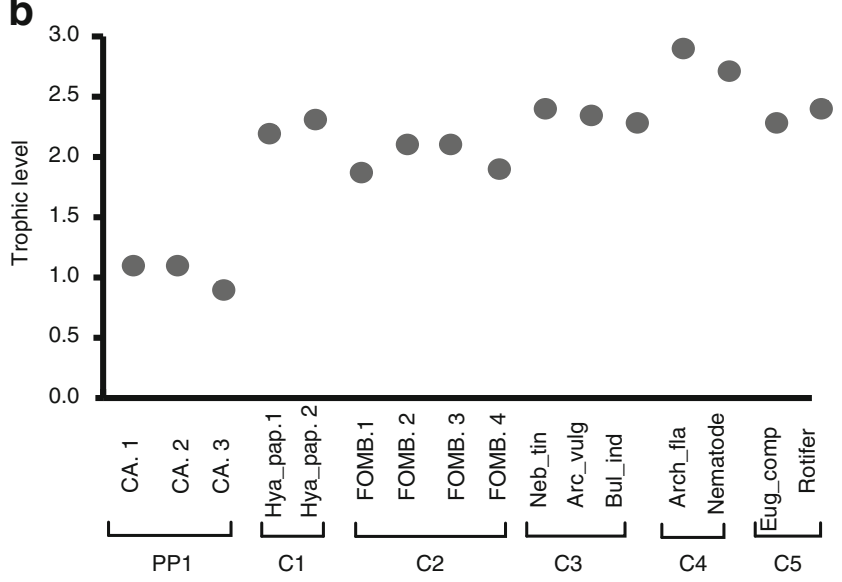

Fig. 3 a Hierarchical clustering (Bray and Curtis index method) of microbial groups and testate amoeba species from $S$. fallax based on their $\delta^{13} \mathrm{C}$ and $\delta^{15} \mathrm{~N}$, isotopic nitrogen and carbon ratio, and trophic level (see text for details). b Trophic level of the different testate amoeba species and microbial groups

and $\mathrm{TP}_{N . \text { tincta }}$, 4.2). Such results are not surprising when we consider the low density of the potential energetic prey for $H$. papilio and $N$. tincta recorded in this study (e.g., ciliates, rotifers, and nematodes). Because of the very low relative abundances of its preferential food sources (i.e., ciliates; [12]), our results suggest that $H$. papilio adapts its feeding behavior by targeting the most abundant and available food sources (e.g., CA). This agrees with the predictions of optimal foraging theory, which states that organisms forage in such a way as to maximize their net energy intake. Optimally foraging organisms can minimize the energy cost of food uptake by targeting the most abundant and easily captured prey $[52,53]$. We estimated that predation of H. papilio on ciliates represented up to $50 \%$ of the total standing biomass of ciliates. This suggests that the density of ciliates was probably lower than a threshold allowing higher active predation of $H$. papilio on this otherwise energetically optimal prey.

Our results reveal that testate amoeba species occupy different TPs in the microbial food web and that these differences could be related to their feeding type. Conversely, this study illustrates that it is difficult to reliably infer the TP of testate amoebae using relatively simple morphological traits without taking into account prey stocks. Food webs usually exhibit a surprisingly consistent topological architecture across different ecosystem types $[4,54]$ mediated by fundamental constraints where species feed on nearly contiguous ranges of mostly lower-ranked species [55]. In general, species with large body size occupy high trophic levels and consume many food sources, whereas smaller species share low trophic levels with more specific food strategies (e.g., bacterivory; [56]). Body size is thus a fundamental indicator of trophic level in food webs because it places constraints on many biological variables, including crucial foraging traits (energy content of resources, handling times, attack rates, and prey density) [57-60]. However, a strong relationship between body size (here, testate amoebae shell length or diameter) and TP cannot be found for consumers that exploit a wide range of prey body sizes [7, 59], as shown here with $H$. papilio and $N$. tincta. Nevertheless, we found
Fig. 4 a Contribution of food sources to the diet of $H$. papilio. Error bars SE, CA microalgae + cyanobacteria. b Trophic level of $H$. papilio vs. the contribution of ciliates and CA to total diet of $H$. papilio. This figure includes some results from Jassey et al. [12]
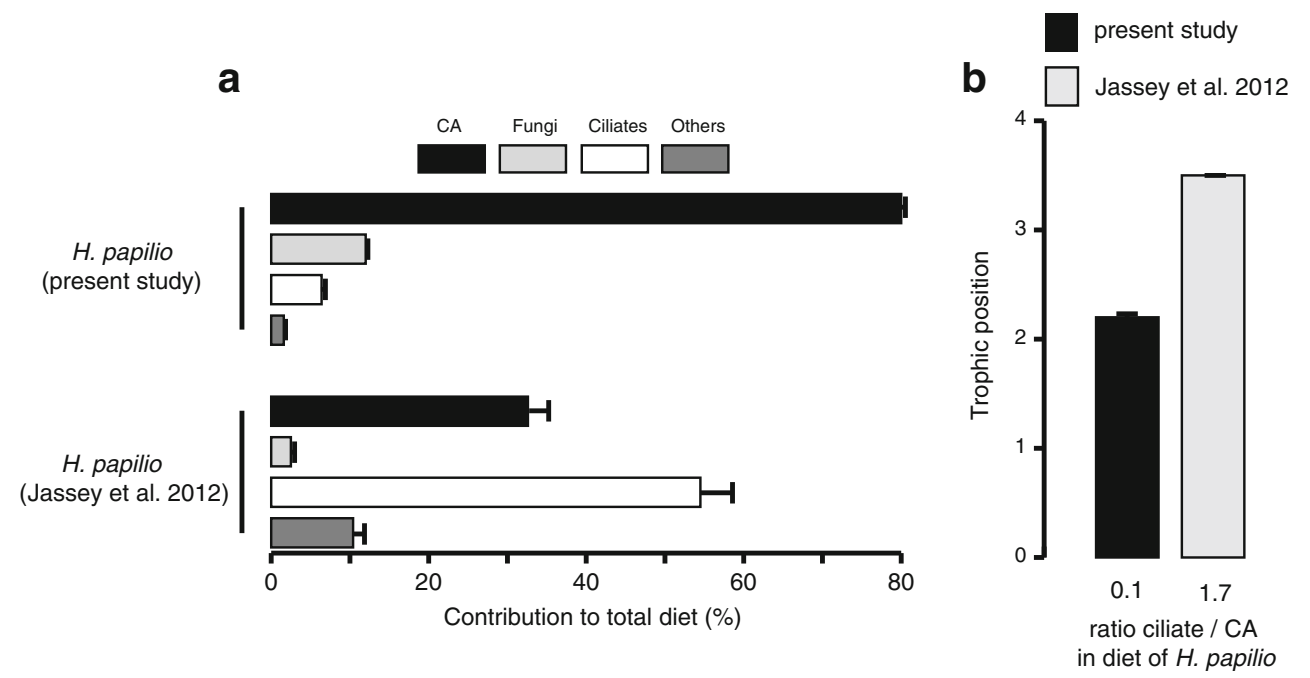
that the size of shell aperture and biovolume were inversely proportional to the TP of testate amoebae in the microbial network, while usually these morphological traits are considered as indicators of high trophic level [12, 25, 27]. Again, such results illustrate the importance of foraging traits such as the density of preferential food sources on the TP of consumers such as H. papilio and $N$. tincta and, therefore, on the food web structure. Indeed, if we compare these results to those of Jassey et al. [12], these data indicate that two morphologically similar populations of the same species (e.g., H. papilio) may occupy very different TPs, thus altering any overall relationship between morphology and TP in Sphagnum-associated food web. Furthermore, the inverse relationship between morphological trait sizes and trophic levels showed that smaller testate amoeba species such as $A$. flavum - found as a consumer of FOMB - occupied the top of the food web. This suggested that bacterivores received more translocated nitrogen from the detritivorous pathway than herbivores from the herbivorous pathway, giving a greater functional role to bacterivores. This isotopic signature of bacteria - and thus their trophic level — depends on the signature of the detrital source, which may sometimes be higher than that of autotrophs [50]. Therefore, a switch from an herbivorous- to a detritivorous-dominant pathway could break down the morphological relationships between trait size and trophic level.

\section{Algal Endosymbiont Contribution to Host H. papilio Diet}

The highly enriched $\delta^{13} \mathrm{C}$ content of $H$. papilio (i.e., $-22 \%$ on average) suggested that this species used another non-identified $\delta^{13} \mathrm{C}$ baseline than other testate amoeba species (i.e., for which the average was $-26 \%$ ), explaining why this species showed such distinct isotopic patterns. An alternative hypothesis is that H. papilio used another source of carbon than CA and ciliates such as their endosymbiotic algae. Few studies have attempted to quantify the energetic benefits of endosymbiotic algae of mixotrophic species, but Schönborn [32] suggested that $H$. papilio could probably live without food sources using these endosymbiotic algae as alternate energy source. The low availability of energetic resources probably led $H$. papilio to use its endosymbionts as complementary energy source and, thus, to receive more translocated carbon from the stimulated activity of its endosymbionts than from CA, explaining why the $\delta^{13} \mathrm{C}$ signature of $H$. papilio was so high. By analogy to our results, Bergschneider and Muller-Parker [61] showed that the $\delta^{13} \mathrm{C}$ signature of zoochlorellae increased from -25 to $-20 \%$ when they were used as complementary energy source in Anthopleura elegantissima. These authors also showed that zoochlorellae anemone exhibited distinctly lower patterns of $\delta^{15} \mathrm{~N}$ values than non-zoochlorellae anemone, indicating that symbiotic anemones received nutrition from both external (heterotrophic) and internal (translocated algal products) sources. Although our results do not allow drawing strong conclusions about the use of endosymbionts as a complementary source of energy in $H$. papilio specimens, they suggest that resource availability may play a fundamental role in the use of endosymbionts as energy source.

The difference between the isotopic signatures of the two mixotrophic species studied (H. papilio and A. flavum) provides evidence in support of the hypothesis that resource availability may play a fundamental role in the use of endosymbionts as energy source. Although obvious morphological differences in overall size and size of shell aperture occur between these mixotrophic species, their range of prey available is likely to explain their different isotopic signatures. These results suggest that mixotrophic species may become more heterotrophic with abundant and available food sources, which alters their functional role in food webs and the carbon cycle. Indeed, a shift toward more heterotrophic nutrition may change the isotopic signature of mixotrophic specimens and, therefore, their functional role from primary production toward consumers [11]. Such results highlight that dynamics in prey-predator abundance could modify the functional role of mixotrophic species in the microbial food web. Furthermore, these results also suggest that mixotrophic species can easily outcompete other competitors when food sources are rare in networks by shifting on their endosymbionts [10]. Hence, our results provide reason to expect that mixotrophic life history trait plays a key role for both prey abundance and microbial food web structure associated to Sphagnum.

In conclusion, our study demonstrates that nitrogen and carbon isotopic signatures of microorganisms are useful for estimating the food web structure of the microbial network associated to Sphagnum. These results show that testate amoeba consumers occupy different trophic levels within the microbial food web, depending on their feeding behavior, the density of their food resources, and their metabolism (i.e., mixotrophy vs. heterotrophy). Our findings provide experimental support for the novel hypothesis that mixotrophy has key implications in food web structure and functioning [62, 63]. Given the key position of mixotrophs in the microbial community in peatlands, changes in their functional role from primary producers to consumers (or vice versa) may cascade through food webs, altering species interactions as well as the magnitude and direction of carbon fluxes.

Acknowledgments This research is a contribution of the ANR

PEATWARM project (Effect of moderate warming on the functioning of Sphagnum peatlands and their function as carbon sink) and the $\mu \mathrm{POL}-$ AIR project (Use of Sphagnum-peatlands to quantify the deposition of long-range air pollutants and to evaluate their impact on environment). PEATWARM is supported by the French National Agency for Research under the "Vulnerability, Environment - Climate" Program (ANR-07VUL-010) and $\mu$ POL-AIR by PRIMEQUAL program (support of French Ministry of Environment and ADEME) (2010-Q.3-Chorus2100082984). Further funding was provided to V.E.J.J. by the Franche-Comté Region, to C.M. by $\mu$ POL-AIR project, and to E.A.D.M. and A.P.C. by the 
University of Neuchâtel. The authors would like to thank T. SimeNgando and J. Colombet (University of Clermont-Ferrand, France) for their help with the flow cytometry and two anonymous reviewers for their valuable comments on the manuscript.

\section{References}

1. Thompson RM, Brose U, Dunne JA, Hall RO Jr, Hladyz S, Kitching RL, Martinez ND, Rantala H, Romanuk TN, Stouffer DB, Tylianakis JM (2012) Food webs: reconciling the structure and function of biodiversity. Trends Ecol Evol 27:689-697

2. Bascompte J (2010) Structure and dynamics of ecological networks. Science 329:765-766

3. De Deyn GB, Raaijmakers CE, van Ruijven J, Berendse F, van der Putten WH (2004) The response of nematodes from different trophic levels in the soil food web to the identity and diversity of plant species. Oikos 106:576-586

4. Ings TC, Montoya JM, Bascompte $\mathrm{J}$, Blüthgen $\mathrm{N}$, Brown $\mathrm{L}$, Dormann CF, Edwards F, Figueroa D, Jacob U, Jones JI, Lauridsen RB, Ledger ME, Lewis HM, Olesen JM, Van Veen FJF, Warren PH, Woodward G (2009) Ecological networks - beyond food webs. J Anim Ecol 78:253-269

5. Rooney N, McCann KS (2012) Integrating food web diversity, structure and stability. Trends Ecol Evol 27:40-46

6. Stouffer DB, Sales-Pardo M, Sirer MI, Bascompte J (2012) Evolutionary conservation of species' roles in food webs. Science 335:1489-1492

7. Kuwae T, Miyoshi E, Hosokawa S, Ichimi K, Hosoya J, Amano T, Moriya T, Kondoh M, Ydenberg RC, Elner RW (2012) Variable and complex food web structures revealed by exploring missing trophic links between birds and biofilm. Ecol Lett 15:347-356

8. Pascal PY, Dupuy C, Richard P, Rzeznik-Orignac J, Niquil N (2008) Bacterivory of a mudflat nematode community under different environmental conditions. Mar Biol 154:671-682

9. Petchey OL, McPhearson PT, Casey TM, Morin PJ (1999) Environmental warming alters food-web structure and ecosystem function. Nature 402:69-72

10. Tittel J, Bissinger V, Zippel B, Gaedke U, Bell E, Lorke A, Kamjunke N (2003) Mixotrophs combine resource use to outcompete specialists: implications for aquatic food webs. Proc Natl Acad Sci U S A 100:12776-12781

11. Wilken S, Huisman J, Naus-Wiezer S, Donk E (2013) Mixotrophic organisms become more heterotrophic with rising temperature. Ecol Lett 16:225-233

12. Jassey VEJ, Shimano S, Dupuy C, Toussaint ML, Gilbert D (2012) Characterizing the feeding habits of the testate amoebae Hyalosphenia papilio and Nebela tincta along a narrow "FenBog" gradient using digestive vacuole content and ${ }^{13} \mathrm{C}$ and ${ }^{15} \mathrm{~N}$ isotopic analyses. Protist 163:451-464

13. Anderson C, Cabana G (2009) Anthropogenic alterations of lotic food web structure, evidence from the use of nitrogen isotopes. Oikos 118:1929-1939

14. Carscallen WMA, Vanderberg K, Lawson JM, Martinez ND, Romanuk TN (2012) Estimating trophic position in marine and estuarine food webs. Ecosphere 3:1-20

15. Mao ZG, Gu XH, Zeng QF, Zhou LH, Sun MB (2012) Food web structure of a shallow eutrophic lake (Lake Taihu, China) assessed by stable isotope analysis. Hydrobiol 683:173-183

16. Schmidt SN, Olden JD, Solomon CT, Vander Zanden MJ (2007) Quantitative approaches to the analysis of stable isotope food web data. Ecology 88:2793-2802
17. Vander Zanden MJ, Rasmussen JB (1999) Primary consumer delta $\mathrm{C}-13$ and delta $\mathrm{N}-15$ and the trophic position of aquatic consumers. Ecology 80:1395-1404

18. Mitchell EAD, Charman DJ, Warner BG (2008) Testate amoebae analysis in ecological and paleoecological studies of wetlands, past, present and future. Biodivers Conserv 17:2115-2137

19. Gilbert D, Amblard C, Bourdier G, Francez AJ, Mitchell EAD (2000) Le régime alimentaire des thécamoebiens (Protista, Sarcodina). Année Biol 3:57-68

20. Gilbert D, Mitchell EAD, Amblard C, Bourdier G, Francez AJ (2003) Population dynamics and food preferences of the testate amoeba Nebela tincta major-bohemica-collaris complex (Protozoa) in a Sphagnum peatland. Acta Protozool 42:99-104

21. Laybourn J, Whymant L (1980) The effect of diet and temperature on reproductive rate in Arcella vulgaris Ehrenberg (Sarcodina, Testacida). Oecologia 45:282-284

22. Yeates GW, Foissner W (1995) Testate amoebae as predators of nematodes. Biol Fertil Soils 20:1-7

23. Meyer C, Bernard N, Moskura M, Toussaint ML, Denayer F, Gilbert D (2010) Effects of urban particulate deposition on microbial communities living in bryophytes, an experimental study. Ecotoxicol Environ Saf 73:1776-1784

24. Meyer C, Gilbert D, Gillet F, Moskura M, Franchi M, Bernard N (2012) Using bryophyte-testate amoebae microsystems as indicators of atmospheric pollution at three different sites (rural, urban and industrial). Ecol Indic 13:144-151

25. Meyer C, Desalme D, Bernard N, Binet P, Toussaint ML, Gilbert D (2013) Using testate amoebae as potential biointegrators of atmospheric deposition of phenanthrene (polycyclic aromatic hydrocarbon) on "moss/soil interface-testate amoebae community" microecosystems. Ecotoxicology 22:287-294

26. Aoki Y, Hoshino M, Matsubara T (2007) Silica and testate amoebae in a soil under pine-oak forest. Geoderma 142:29-35

27. Jassey VEJ, Chiapusio G, Binet P, Buttler A, Laggoun-Défarge F, Delarue F, Bernard N, Mitchell EAD, Toussaint ML, Francez AJ, Gilbert D (2013) Above- and belowground linkages in Sphagnumpeatland: warming affects plant-microbial interactions. Glob Chang Biol 19:811-823

28. Schröter D, Wolters V, De Ruiter PC (2003) C and N mineralization in the decomposer food webs of a European forest transect. Oikos 102:294-308

29. Wilkinson DM, Mitchell EAD (2010) Testate amoebae and nutrient cycling with particular reference to soils. Geomicrobiol J 27:520-533

30. Fournier B, Malysheva E, Mazei Y, Moretti M, Mitchell EAD (2012) Toward the use of testate amoeba functional traits as indicator of floodplain restoration success. Eur J Soil Biol 49:85-91

31. Chacharonis P (1956) Observations on the ecology of protozoa associated with Sphagnum. J Protozool 3:11

32. Schönborn W (1965) Untersuchungen über die ZoochlorellenSymbiose der Hochmorr-Testacean. Limnology 5:173-176

33. Booth RK, Sullivan ME, Sousa VA (2008) Ecology of testate amoebae in a North Carolina pocosin and their potential use as environmental and paleoenvironmental indicators. Ecoscience 15:277-289

34. Heal OW (1962) Abundance and microdistribution of testate amoebae (Protozoa: Rhizopoda) in Sphagnum. Oikos 13:35-47

35. Heal OW (1964) Observations on the seasonal and spatialdistribution of Testacea (Protozoa, Rhizopoda) in Sphagnum. J Anim Ecol 33:395-412

36. Heal OW (1961) The distribution of testate amoebae (Rhizopoda: Testaecea) in some fens and bogs in Northern England. Zool J Linnean Soc 44:369-382

37. Flynn KJ, Stoecker DK, Mitra A, Raven JA, Glibert PM, Hansen PJ, Graneli E, Burkholder JM (2012) Misuse of the phytoplankton-zooplankton dichotomy: the need to assign organisms as mixotrophs within plankton functional types. J Plankton Res. doi:10.1093/plankt/fbs062 
38. Hartmann M, Grob C, Tarran GA, Martin AP, Burkill PH, Scanlan DJ, Zubkov MV (2012) Mixotrophic basis of Atlantic oligotrophic ecosystems. Proc Natl Acad Sci U S A 109:5756-5760

39. Uthermölh H (1958) Zur vervollkommnung der quantative phytoplankton-methodik. Mitteilungen aus Institut Verhein Limnology 3:1-38

40. Bratbak G (1985) Bacterial biovolume and biomass estimations. Appl Environ Microbiol 49:1488-1493

41. Weisse T, Muller H, Pintocoelho RM, Schweizer A, Springmann D, Baldringer G (1990) Response of the microbial loop to the phytoplankton spring bloom in a large prealpine lake. Limnol Oceanogr 35:781-794

42. Gilbert D, Amblard C, Bourdier G, Francez AJ (1998) The microbial loop at the surface of a peatland, structure, function, and impact of nutrient input. Microb Ecol 35:83-93

43. Post DM (2002) The long and short of food-chain length. Trends Ecol Evol 17:269-277

44. Fox J, Weisberg S (2011) An R companion to applied regression, 2nd edn. Sage, Thousand Oaks

45. Oksanen J, Blanchet G, Kindt R, Legendre P, O'Hara RG, Simpson GL, Solymos P, Stevens MHH, Wagner H (2010) Vegan, community ecology package. R package version 1.17-1. Available at http:// CRAN.R-project.org/package $=$ vegan

46. R Development Core Team (2012) R, a Language and Environment for Statistical Computing. R Foundation for Statistical Computing, Vienna

47. Kohzu A, Iwata T, Kato M, Nishikawa J, Wada E, Amartuvshin N, Namkhaidorj B, Fujita N (2009) Food webs in Mongolian grasslands: the analysis of ${ }^{13} \mathrm{C}$ and ${ }^{15} \mathrm{~N}$ natural abundances. Isot Environ Health Stud 45:208-219

48. Segers H (2008) Global diversity of rotifers (Rotifera) in freshwater. Hydrobiol 595:49-59

49. Sharma BK (2005) Rotifer communities of floodplain lakes of the Brahmaputra basin of lower Assam (NE India), biodiversity, distribution and ecology. Hydrobiol 533:209-221

50. Ponsard S, Arditi R, Jost C (2000) Assessing top-down and bottomup control in a litter-based soil macroinvertebrate food chain. Oikos $89: 524-540$

51. Scheu S, Falca M (2000) The soil food web beech forests (Fagus sylvatica) of contrasting hulus type: stable isotope analysis of a macro- and a mesofauna-dominated community. Oecol 123:285296

52. Akin S, Winemiller KO (2008) Body size and trophic position in a temperature estuarine food web. Acta Oecol 33:144-153

53. Stephens DW, Krebs JR (1986) Foraging Theory. Princeton University Press, Princeton

54. Schneider FD, Scheu S, Brose U (2012) Body mass constraints on feeding rates determine the consequences of predator loss. Ecol Lett $15: 436-443$

55. Stouffer DB, Camacho J, Amaral LAN (2005) Quantitative analysis of the local structure of food webs. Ecology 86:1301-1311

56. Brose U, Dunne JA, Montoya JM, Petchey OL, Schneider FD, Jacob U (2012) Climate change in size-structured ecosystems introduction. Phil Trans R Soc Biol Sci 367:2903-2912

57. Barnes C, Maxwell D, Reuman DC, Jennings S (2010) Global patterns in predator-prey size relationships reveal size dependency of trophic transfer efficiency. Ecology 91:222232

58. Heckmann L, Drossel B, Brose U, Guill C (2012) Interactive effects of body-size structure and adaptive foraging on food-web stability. Ecol Lett $15: 243-250$

59. Layman CA, Winemeller KO, Arrington DA, Jepsen DB (2005) Body size and trophic position in a diverse tropical food web. Ecology 86:2530-2535

60. Thierry A, Petchey OL, Beckerman AP, Warren PH, Williams RJ (2011) The consequences of size dependent foraging for food web topology. Oikos 120:493-502

61. Bergschneider H, Muller-Parker G (2008) Nutritional role of two algal symbionts in the temperate sea anemone Anthopleura elegantissima Brandt. Biol Bull 215:73-88

62. Lopez-Urrutia A, San Martin E, Harris RP, Irigoien X (2006) Scaling the metabolic balance of the oceans. Proc Natl Acad Sci U S A 103:8739-8744

63. Yvon-Durocher G, Jones JI, Trimmer M, Woodward G, Montoya JM (2010) Warming alters the metabolic balance of ecosystems. Philos Trans R Soc B Biol Sci 365:2117-2126

64. 2Yeates GW, Bongers T, Degoede RGM, Freckman DW, Georgieva SS (1993) Feeding-habits in soil nematode families and genera - an outline for soil ecologists. J Nematol 25:315-331 